\title{
A Critical Analysis of the Influence of Tafsir al-Tha'labi in Tafsir Nur Al-Ihsan Based on Genetic Approach
}

\author{
Mohd Sholeh Sheh Yusuff, Yusuf Haji-Othman, Mohamad Hazli Ismail
}

To Link this Article: http://dx.doi.org/10.6007/IJARBSS/v11-i6/10370

DOI:10.6007/IJARBSS/v11-i6/10370

Received: 12 April 2021, Revised: 15 May 2021, Accepted: 30 May 2021

Published Online: 21 June 2021

In-Text Citation: (Yusuff et al., 2021)

To Cite this Article: Yusuff, M. S. S., Haji-Othman, Y., \& Ismail, M. H. (2021). A Critical Analysis of the Influence of Tafsir al-Tha'labi in Tafsir Nur Al-Ihsan Based on Genetic Approach. International Journal of Academic Research in Business and Social Sciences, 11(6), 1442-1447.

\section{Copyright: @ 2021 The Author(s)}

Published by Human Resource Management Academic Research Society (www.hrmars.com)

This article is published under the Creative Commons Attribution (CC BY 4.0) license. Anyone may reproduce, distribute, translate and create derivative works of this article (for both commercial and non-commercial purposes), subject to full attribution to the original publication and authors. The full terms of this license may be seen at: http://creativecommons.org/licences/by/4.0/legalcode

Full Terms \& Conditions of access and use can be found at http://hrmars.com/index.php/pages/detail/publication-ethics 


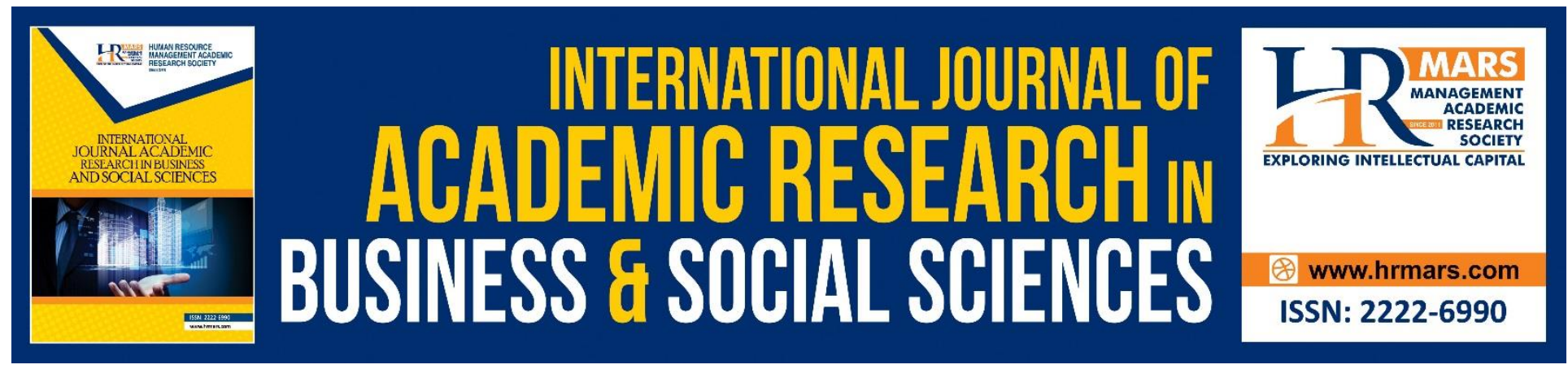

\title{
A Critical Analysis of the Influence of Tafsir al- Tha'labi in Tafsir Nur Al-Ihsan Based on Genetic Approach
}

\author{
Mohd Sholeh Sheh Yusuff, Yusuf Haji-Othman, Mohamad Hazli \\ Ismail \\ Sultan Abdul Halim Mua'dzam Shah International Islamic University, 09300 Kuala Ketil, Kedah, \\ Malaysia
}

\begin{abstract}
Tafsir Nur al-Ihsan is a book in the field of Quranic exegesis written by Syeikh Muhammad Sa'id bin Umar. The Muslim community has used this book as a reference to understand the meaning of the al-Quran. However, there is a tremendous amount of denunciation done towards the book by the community due to the lack of clear resources in translating verses of al-Quran, which has confused the community on the legality of the translation done in the book. Therefore, this study is important to reveal the reference sources used by the author of the work. This can eliminate public confusion about this work. The research design used is documentation and fieldwork using the subjective approach that employs descriptive and qualitative data. The main objective of this research is to study and detect the original resources of the writer in the Tafsir Nur al-Ihsan, and expressing how the sources are taken from the Quranic verses. The analysis of Tafsir Nur al-Ihsan used the genetic approach which Goldman publicized in studying the origin of the resources. While carrying out the research, the researcher referred to the text from Tafsir Nur al-Ihsan and Tafsir Al-Tha'labi and compared both texts to detect the similarities and differences. The result of the analysis proved that Syeikh Muhammad Sa'id successfully strengthens his interpretation because the contents of the text in Tafsir Nur al-Ihsan are parallel to the references. This study suggests that thorough research be done by the next researcher on all the works referred to by Sheikh Muhammad Said when writing Tafsir Nur al-Ihsan. This is to completely remove the public's doubts about this work.
\end{abstract}

Keywords: Tafsir Nur al-Ihsan, Tafsir Al-Tha'labi, Genetic Approach, Comparison, Reference

\section{Introduction}

Tafsir Nur al-Ihsan is a tafsir of the Qur'an that is still used as a teaching and reference material until now, especially in institutions of learning, in mosques, and musollas. For example, weekly studies at Pondok Tuan Guru Haji Bakar Parit Panjang, Baling Kedah Malaysia and Pondok Tuan Guru Haji Soleh Musa in Sik Kedah Malaysia. However, the author of tafsir in his work does not clearly state the source of the quotation in interpreting the verses of the Qur'an. That has confused the public about the validity of the interpretation he has made (Zaim, 2010). The writing of this work has shortcomings because there is a lack of writing style that does not state 
the source of facts and weaknesses due to the author's use of many unfounded opinions in his interpretation (Zaim, 2010). The stories in this work are also dubious as the author does not describe the reference source in detail. Therefore, the community needs to be careful when reading and referring to this work (Taib, 2003).

Considering that Tafsir Nur al-Ihsan is still used as teaching material in the interpretation of the Qur'an and community reference in understanding the holy verses of the Qur'an, then the effort to purify this work should be done (Yusuff, 2020). One form of such effort is through studies that use a genetic approach that will reveal and find the origin of the data used by the author when writing Tafsir Nur al-Ihsan (Sohaimi, 2001). In conducting this research, the researchers applied the source study, one of the research methods in the genetic approach. Through this method, researchers will dissect and identify the source of the text referred to by Sheikh Muhammad Said in producing Tafsir Nur al-Ihsan and revealing how the author processes the text referred to in his work (Sohaimi, 2001). Moreover, this research only focuses on the text from Tafsir Al-Tha'labi referred to by Sheikh Muhammad Said as an initial effort towards refining Tafsir Nur al-Ihsan and also as an example of the ability to apply genetic approaches to works in the field of tafsir al-Quran, which in turn can be expanded to other reference works, which will undoubtedly contribute towards the perfection of the work of Tafsir Nur al-Ihsan.

\section{Research Methodology}

In conducting this research, the researchers applied a genetic approach. Through a genetic approach, researchers examine and show the origin of a written work or how work has influenced the writing of another author's work (Sohaimi, 2001). For example, Tafsir Pimpinan al-Rahman by Abdullah Basmeih has been influenced by Tafsir Al-Tha'labi by Ibn Jarir (Basmeih, 2000) Tafsir AlTha'labi by Al-Tha'labi (Basmeih, 2000) and Ruh al-Ma'ani by al-Alusi (Basmeih, 2000). Initially, an author writes his or her work after reading, researched, and understood the text of a work that has caught his or her attention either consciously or unconsciously (Ronidin, 2011). The author processes the text from the books he reads and then he transfers the text into his work (Ronidin, 2011).

The word genetic comes from the root word "gene", and in Greek, genea means breed, kind and Gene means seed (Sinar, 2003). This genetic approach is a study of the relationship between works that show similarities based on seed or origin factors (Sinar, 2003). Another word related to it is genesis, which encompasses the origin, production, and creation (Sinar, 2003). According to Ronidin (2011), the genetic approach is also known as the study of influence and influence in a text. This approach is more accurately said to be a source study or an original study that discusses where exactly an influence comes from (Ronidin, 2011).

According to Lubis (1994), the genetic approach is divided into five aspects, namely influence, adaptation, plagiarism, imitation, and translation. Among the five aspects, the one that is rather difficult to separate is imitation and influence (Lubis, 1994). This is due to judging a work whether it imitates or has been influenced by other works is only known by the author of the work itself because what can distinguish between imitation and influence is the element that involves intentional and unintentional acts (Lubis, 1994). This means when the author makes an imitation; he does so intentionally and consciously. Conversely, influence occurs when the author does so unintentionally. However, it is very rare for an author to admit that his writing is through imitation or influence (Lubis, 1994). Shaw (1990) states: 
"A writer can be said to be influenced by another writer when evidence from outside can be made the material of a sufficiently convincing study. In contrast to imitation, the work of the affected author is recognized as his. Influence is something very broad happening anywhere and anytime".

Through the study of sources, the researchers analyzed the original text of Tafsir Al-Tha'labi used by Sheikh Muhammad Said in producing a work entitled Tafsir Nur al-Ihsan. When researchers want to find the original text for the work of Tafsir Nur al-Ihsan, the research process ensures that researchers make a comparison between Tafsir Nur al-Ihsan and Tafsir Al-Tha'labi. This process of comparison is to find out the similarities and differences between the two texts. If the written text is in line with the referenced text, it reinforces the author's interpretations. But on the other hand, if the written text is different from the text from Tafsir Al-Tha'labi, this confuses the author's text.

\section{Discussion}

This research is conducted on five aspects in Tafsir Nur al-Ihsan, including The Contexts and Occasions of the Revelation of the Qur'an (Sabab Nuzul Ayah), hadiths (al-Hadith), the stories of Isra'iliyyat (al-Isra'iliyyat), The Abrogating and Abrogated Verses in the Qur'an (Nasikh and Mansukh) and The Text about Advantages (Fadhilat) (Umar, 1970). The researchers chose these five aspects because they are the primary debates of the author in the work (Umar, 1970). However, only one aspect is discussed by the author based on his reference to Tafsir Al-Tha'labi, namely the text on al-Isra'iliyyat (Umar, 1970).

Sheikh Muhammad Said has used three methods when transferring the text from Tafsir AlTha'labi into Tafsir Nur al-Ihsan, namely quoting the text in parallel, quoting the text in the abstract, and dropping some words found in the text of Tafsir Al-Tha'labi (Umar, 1970). This is shown in Table 1.

Table 1: The way the author uses the text of Tafsir Al-Tha'labi

\begin{tabular}{lllllllll}
\hline No. & Aspects & Parallel & $\begin{array}{l}\text { Abstrac } \\
\mathrm{t}\end{array}$ & $\begin{array}{l}\text { Droppi } \\
\mathrm{ng}\end{array}$ & $\begin{array}{l}\text { Addin } \\
\mathrm{g}\end{array}$ & $\begin{array}{l}\text { Changi } \\
\mathrm{ng}\end{array}$ & $\begin{array}{l}\text { Tota } \\
\text { l }\end{array}$ & Percent \\
\hline $\mathbf{0 1}$ & $\begin{array}{l}\text { Sabab Nuzul } \\
\text { Ayah }\end{array}$ & 0 & 0 & 0 & 0 & 0 & $\mathbf{0}$ & $\mathbf{0}$ \\
& Al-Hadith & 0 & 0 & 0 & 0 & 0 & $\mathbf{0}$ & $\mathbf{0}$ \\
\hline $\mathbf{0 2}$ & Al-lsra'iliyyat & 1 & 2 & 3 & 0 & 0 & $\mathbf{6}$ & $\mathbf{1 0 0}$ \\
\hline $\mathbf{0 3}$ & Nasikh & 0 & 0 & 0 & 0 & 0 & $\mathbf{0}$ & $\mathbf{0}$ \\
\hline $\mathbf{0 4}$ & Mansukh & & & & & & & $\mathbf{0}$ \\
\hline $\mathbf{0 5}$ & Fadhilat & 0 & 0 & 0 & 0 & 0 & $\mathbf{0}$ & $\mathbf{0}$ \\
\hline & Total & $\mathbf{1}$ & $\mathbf{2}$ & $\mathbf{3}$ & $\mathbf{0}$ & $\mathbf{0}$ & $\mathbf{6}$ & $\mathbf{1 0 0}$ \\
\hline & Percent & $\mathbf{1 6 . 6}$ & $\mathbf{3 3 . 3}$ & $\mathbf{5 0}$ & $\mathbf{0}$ & $\mathbf{0}$ & $\mathbf{1 0 0}$ & \\
& & & & & & & & \\
& & & & & & & &
\end{tabular}


Table 1 indicates that Sheikh Muhammad Said has practiced three ways in using the text from Tafsir Al-Tha'labi, which is referred to when writing Tafsir Nur al-Ihsan. First, he quoted the text in parallel from Tafsir Al-Tha'labi where the text written by him is the same as the original text from the text of Tafsir Al-Tha'labi, i.e., 1 text (16.6\%) of al-Isra'iliyyat (Umar, 1970).

Second, the author quotes the meaning of the text contained in Tafsir Al-Tha'labi and then he includes it in Tafsir Nur al-Ihsan (Umar, 1970). This second way means that when the author refers to Tafsir Al-Tha'labi and understands its contents, he translates his understanding into his work through a new verse arrangement in his way. The resulting excerpt is in abstract form following the original work referred to. Only the meaning of the text is similar to each other, but the form of the text is different (Sohaimi, 2001). There are 2 texts (33.3\%) where the author refers to Tafsir Al-Tha'labi in this second way, namely the text on al-Isra'iliyyat (Umar, 1970).

The third is the last way that, the author omits certain verses or sentences from Tafsir Al-Tha'labi after he quotes the text from the work (Umar, 1970). He did so with texts that were too long to make it difficult for the public to understand. These abortions often involve data on al-Isra'iliyyat that have various opinions and discussions of scholars about it or other deemed inappropriate opinions if loaded together. Therefore, the author selects only some opinions to be adapted in his work, and some other opinions are dropped. There are 3 texts (50\%) in which the author applies this third way, namely text on the al-Isra'iliyyat (Umar, 1970).

\section{Conclusion}

Based on the research and analysis that has been done, the study found that Sheikh Muhammad Sa'id has only one purpose when referring to the text from Tafsir Al-Tha'labi; that is, he merely wishes to reinforce the interpretations and descriptions that have been made. Thus, the study found that the authors have successfully realized that goal.

The success of the author results when the text is written about an aspect, for example, the alIsra'iliyyat in Tafsir Nur al-Ihsan is in line with the text referred to from Tafsir Al-Tha'labi, whether the equation fits the form of the text or the content of the text (Sohaimi, 2001). For example, the author refers to a text from Tafsir Al-Tha'labi (Al-Tha'labi, 2004);

$$
\begin{aligned}
& \text { فأخذ بيد أخته هبة الله ذهب بها إلى عدن من أرض اليمن ، فأتاه إبليس ، فقال له : إنما إنما أكلت النار قريان هابيل لأنه كان يعبد }
\end{aligned}
$$

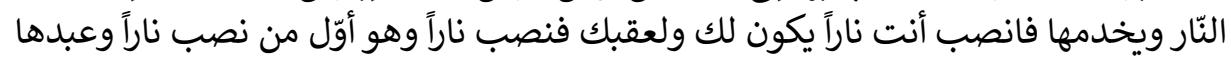

While the text from Tafsir Nur al-Ihsan, the author writes, "He (Qabel) held his sister's hand and went to Udun, Yemen. So the devil came to him and said: Surely the gift (Habel) of being struck by fire shows that he is a worshiper of fire, therefore, you need to build a house of fire. He (Qabel) was the first to worship fire (Umar, 1970)".

The study found that the author had referred to the text from the work and then included it in Tafsir Nur al-Ihsan in parallel without adding or subtracting sentences at all. The example proves that Sheikh Muhammad Sa'id has succeeded in strengthening the interpretation that has been made in Tafsir Nur al-Ihsan.

Therefore, this article concludes that the genetic approach that has been applied in conducting this research is a comparative study approach in the field of literature. This approach is used to 
detect the influences that have influenced work by comparing one influence with another (Shaw, 1990). This approach involves three patterns, namely source study, mediator study, and acceptance study (Sohaimi, 2001). This study applies the analysis of sources in analyzing and identifying the original reference from Tafsir Al-Tha'labi used by Sheikh Muhammad Sa'id when producing Tafsir Nur al-Ihsan, in addition to showing how Sheikh Muhammad Sa'id transferred the text referenced into his work.

Based on the analysis that has been made, Tafsir Al-Tha'labi is used as a reference by Sheikh Muhammad Sa'id to the one aspect contained in Tafsir Nur al-Ihsan, namely, the text on alIsra'iliyyat represents 6 texts (100\%) (Umar, 1970).

Therefore, this article proves that Sheikh Muhammad Sa'id, in producing this work entitled Tafsir Nur al-Ihsan, did not use unfounded facts or use his own opinion in creating Tafsir Nur al-Ihsan he has made Tafsir Al-Tha'labi is one of the works that became his reference in interpreting the holy verses of the Quran.

\section{References}

Al-Tha'labi, A. I. (2004) Tafsir Al-Tha'labi. Beirut: Dar al-Kutub al-Ilmiyyah.

Basmeih, A. (2000). Tafsir Pimpinan al-Rahman Kepada Pengertian al-Qur'an. Cetakan ke-16. Kuala Lumpur: Dar al-Fikr.

Lubis, M. B. (1994). Pendekatan Genetik dalam Kesusasteraan Bandingan: Beberapa Pengantar Awal dalam Jaafar Husin (ed.), Pengantar Kesusasteraan Bandingan. Kuala Lumpur: Dewan Bahasa dan Pustaka.

Ronidin. (2011). Malin Kundang, Ibunya Durhaka. Lingua Didaktika, Volume 4 No 2, 114-125.

Shaw, J. T. (1990). "Keberhutangan Kesusasteraan dan Kajian Sastera Bandingan", dalam Newton P. Stallknecht dan Horst Frenz (ed.), Sastera Perbandingan: Kaedah dan Perspektif, Kuala Lumpu: Dewan Bahasa dan Pustaka.

Sinar, T. T. Z. (2003). Pancaran Filosofis Rabindranath Tagore dan Hinduisme pada Sanusi Pane: Satu Pendekatan Genetik. Studia Kultura, Nomor 3 Tahun 2, 211-228.

Sohaimi, A. Z. (2001). Kesusasteraan Bandingan: Perkembangan, Pendekatan Praktis. Kuala Lumpur: Utusan Publications \& Distributors Sdn. Bhd.

Taib, M. I. (2003). Israiliyyat Dalam Tafsir: Kajian Terhadap Kitab Nur al-Ihsan, Karya Haji Muhammad Said bin Umar. Disertasi Sarjana Pengajian Islam, Universiti Malaya.

Umar, M. S. (1391H/1970M). Tafsir Nur al-Ihsan. Fatani: Matba'ah Bin Halabi.

Yusuff, M. S. (2020). Bacaan Intertekstual Terhadap Tafsir Nur al-Ihsan: Kajian Menurut Kaedah Ekspansi, Jurnal Dunia Pengurusan, Vol. 2, No. 2, 1-11, 2020.

Zaim, M. N. (2010). Kajian Takhrij Hadith Dalam Tafsir Nur Al-Ihsan.Disertasi Sarjana Sastera, Universiti Sains Malaysia. 